\title{
A view of innovation process in a collaborative perspective
}

Thais B. Zaninelli

\begin{abstract}
Introduction: Service innovation and New Service Development process has changed throughout the past years. Nowadays it is accepted that its process involves four generic phases, from the idea generation to the implementation stage. In these stages, some factors are recognized as important and given the complexity, the new service development process by a single company can be facilitated thought of relationships with other companies. Therefore, this research aimed to understand how collaborative networks can influence new service development process performance. Method: Exploratory multiple case study and a qualitative study. Results: Some performance factors cross-cut all process, however, the relevance of these factors changes along these different stages. Conclusions: Quality factors of Collaborative Networks that contribute to the process performance can be classified into two dimensions: 1) partner characteristics and 2) relationship characteristics.
\end{abstract}

\section{Keywords}

Service innovation. Innovation processes. Service development. Collaborative networks.

\section{Introduction}

In the last decades, Service Innovation has gained increased attention (OJANEN; LANNE et al., 2008). However, many processes of New Service Development (NSD) still stem from the New Product Development (NPD) field (SCHEUING; JOHNSON, 1993; AKAMAVI, 2005) and some researchers still believe that existing manufacturing and goods-derived business processes can be readily applied to services (OSTROM; BITNER et al., 2010).

A remarkable number of researchers and executives have attempted toidentify stages that are crucial for the NSD process success and nowadays this process has described in the literature by a complex sequential process that emphasizes an organizational perspective concentrating on four generic phases, from the service idea generation to the service implementation (EDVARDSSON; GUSTAFSSON et al., 2000). These phases can be carried out by a single company or by establishing relationships between inter-company partners of different sectors (VALKEAPAA et al., 2006).
Despite the growing interest in NSD in the recent past, the NSD process is still understudied (SUNDBO, 1997; TAX; STUART, 1997; EDVARDSSON; GUSTAFSSON et al., 2000; SYSON; PERKS, 2004) especially when this process involves collaboration of a network of partner companies (VALKEAPAA et al., 2006; CHEN; TSOU; CHING, 2011). The establishment of Networks in NSD process context represents a vital source of knowledge and collaborative potential (HÅKANSSON; SNEHOTA, 1989).

Thus, it becomes increasingly relevant to promote global service research agendas that concomitantly draw on the interdisciplinary and cross-functional perspective of academics and business executives (OSTROM; BITNER et al., 2010) to study NSD process. However, NSD and Collaborative Networks can be find in the literature separately, but NSD process and collaborative network in the same context is still hard to find.

Therefore, this study contributes to understand how collaborative networks can lead to NSD 
process performance and how these networks evolve along the NSD stages.

This study involved exploratory multiple case study and qualitative studies in four complex NSD projects. The results contribute to understand NSD process stages; characterize the CNs created along the NSD process; and analyze how CNs evolve and influence NSD process performance across NSD stages.

This paper is organized into the following sections: conceptual background addresses the Literature Review that covers studies on main concepts referring to this research, named New Service Development and Collaborative Networks. Research method which involves: method, sampling and data collection and analysis. The next section reports on the results and the last section presents the discussions of the findings and the paper concludes with research implications and suggestions for future research.

\section{Conceptual Background}

\section{New service development and collaborative networks}

Service Innovation or New Service Development (NSD) process is a way of creating competitive advantage and value for customers by offering new or improved services. The NSD uses both tangible and intangible elements of production that increase the value-in-use or benefits for customers (OTTENBACHER; GNOTH; JONES, 2006).

Many service firms still have not adopted formalized or well structured NSD processes (KELLY; STOREY, 2000; FITZSIMMONS; FITZSIMMONS, 2001) and are still using a "hit-and-miss approach" when developing new services (DE BRENTANI, 1989). Other service companies believe that new services "happen" due to luck, intuition, imagination or competitive action of the opponents (SCHEUING; JOHNSON, 1993; MENOR; TATIKONDA;
SAMPSON, 2002) instead of adopting a formal NSD process.

This paradigm started to be broken through two research fronts. On the one hand, several studies proved that the organizations that adopted formal innovation mechanisms had better opportunities to develop new services that reached their objectives (DE BRENTANI, 1991; COOPER; EASINGWOOD et al., 1994; EDGETT, 1994). On the other hand, several researchers proposed innovation structured processes for new service development (EDVARDSSON; GUSTAFSSON et al., 2000).

However, there is no standard model universally recognized for the NSD process, although some authors advocate that the NSD should follow a logical process, including a set of activities and tasks which are done in a sequential or parallel way (TAX; STUART, 1997; EDVARDSSON; GUSTAFSSON et al., 2000; ALAM; PERRY, 2002).

Due to these several activities and tasks involved along different stages of NSD process, research has shown that more formal and structured processes enable lower cost and service time to market (FROEHLE; ROTH et al., 2000). Therefore, the NSD process becomes an important competitive advantage in the current scenery marked by the strong competitiveness.

Empirical studies highlighted that companies using a formal procedure succeed more frequently, even if the duration of development process is longer (REIDENBACH; MOAK, 1986). These studies show that, using formal NSD processes increases the probability of having good results (EDGETT, 1994).

Several researchers applied sequential models to NSD (ROSENFELD, 1997; TAX; STUART, 1997; MARTIN; HORNE; SCHULTZ, 1999; EDVARDSSON; GUSTAFSSON et al., 2000; ALAM; PERRY, 2002) that involves several stages ranging from service idea generation to market introduction. 
Edvardsson, Gustafsson and Roos (2005) highlight that the NSD process can be organized into four main stages: service idea generation; service strategy and culture gate; service design and service policy deployment and implementation. However, these stages can be changed depending on the organizational context and of the new service characteristics.

Based on what was mentioned, there is a complexity involved along all these NSD stages (OJANEN; LANNE et al., 2008) given the intra and extra-organizational activities and tasks which are necessary to undertake all NSD process (ALBRECHT, 2000). Due to this complexity, the different process stages can be carried out by several companies through the establishment of collaborative relationships helping to potentiate NSD performance (VALKEAPAA et al., 2006).

From the various forms of cooperation among companies, the most evident in the last years is the Collaborative Networks (CNs), involving the cooperation between two or more partner companies, customers or providers that intend to develop a new service or product together (JOHNSON; SCHOLES; WHITTINGTON, 2007).

The $\mathrm{CN}$ phenomenon in the business context is relatively recent. It designates any type of network (relationships among people, groups and companies) that has some type of interaction, from the professional communities to the supply chain, and that has as main goals sales and profit generation through: $R \& D$, export, product development and problem solution (ROSENFELD, 1997).

A CN is constituted by a variety of entities (e.g., organizations and people) that are largely autonomous, geographically distributed, and heterogeneous in terms of their operating environment, culture, social capital, and goals (CAMARINHA-MATOS; AFSARMANESH, 2008). These entities collaborate to better achieve common or compatible goals (LEWIS, 1992; ROSENFELD, 1997).
The relationships established with partner companies along the different NSD stages can influence the NSD performance and consequently new service success. These networks established between different stakeholders are increasingly adopted in the modern management with the aim of dividing risks, reducing costs, increasing quality patterns and optimizing product and service development processes (JOHNSON; SCHOLES; WHITTINGTON, 2007). However, previous research indicates that only one in each five organizations have pre-established orientations to maintain relationship network success (AUSTIN, 2000). A formal management of this process is still hard to find, and is seldom effective.

Despite the importance collaborative role of the different stakeholders in NSD is still an unexplored area (STEVENS; DIMITRIADIS, 2005; VALKEAPAA et al., 2006; LUSCH; VARGO; TANNIRU, 2010) and there is no consensual definition of Collaborative Networks (CNs). This situation constitutes a major obstacle for the interaction among experts from multiple disciplines involved in this area and creates an obstacle for the recognition of $\mathrm{CNs}$ as a new scientific discipline (CAMARINHA-MATOS; AFSARMANESH, 2005; TETHER; TAJAR, 2008).

Therefore, research on CNs in the NSD context is needed for the development of formal theories and models, not only to better understand the area but also as the basis for the development of methods and tools for decision-making (CAMARINHA-MATOS; AFSARMANESH, 2008).

In order to fulfill these gaps, this study identified desirable CNs quality factors in complex NSD projects in different stages. The study started with an exploratory multiple case study involving four NSD complex projects of the shopping mall type. The objective of this exploratory study was to characterize the main stages of the process and to analyze when and how CNs were formed. After this, a qualitative study was undertaken to obtain an in-depth understanding of the NSD 
process, CNs quality factors and how these factors evolve along NSD stages and influence NSD performance.

In this way, this study contributes to understand how CNs can lead to NSD process performance and how these CNs evolve along the NSD stages.

\section{Research Design}

This research aimed at understanding how CNs can influence NSD performance and final service success. The study identifies CNs quality factors in complex NSD projects, analyzing how they can potentiate the NSD performance along the different stages. This way, the management of $\mathrm{CN}$ in the NSD context is a complex and new research area.

Therefore, the present study adopted qualitative research (DENZIN; LINCOLN, 2000) as it is considered adequate to provide an in-depth understanding of novel phenomena.

The research comprised two main stages: The first exploratory stage involved a preliminary study of the four projects of a company that runs an international chain of shopping malls. This study aimed to understand the main NSD stages and the CN developed along these stages. The second research stage involved a qualitative study with companies involved in the $\mathrm{CN}$ of the different NSD projects. This study aimed to get an in-depth understanding of CN quality factors that influence the NSD performance as well as these factors evolve across NSD stages.

For both Exploratory Multiple Case Study and Qualitative Study, the empirical field covered four complex NSD Projects of the Shopping Mall type that were developed in the $\mathrm{CN}$ context and which were at different stages of the NSD process. These projects were located in Portugal and Brazil, and each one was in a different NSD stage: idea generation and conceptual project development (early stages) (Brazil); Construction Stage (Portugal); Launch Stage (Portugal); and Operation Stage (Brazil). The first project covered the first two phases (idea generation and conceptual project development) of the NSD process, as the activities were undertaken almost simultaneously and in close connection.

The Exploratory Multiple Case Study followed a Grounded Theory (CHARMAZ, 2006) approach as it is well suited to deepen the knowledge about a specific phenomenon and develop theories. Therefore, it was necessary to research several environments in a natural context to describe the phenomena as it really happens. These facts are understood based on several evidence sources and the researcher does not directly intervene on these results but understands them.

The sample of exploratory study involved managers that work in different collaborative networks and directly in the NSD projects. The data collection was based on participant observation, interviews and analysis of documents undertaken in São Paulo city - Brazil and Porto city and Lisboa city, both in Portugal. The company under study provided all necessary documents to analyze in detail the complex NSD process of shopping mall type. Based on participant observation of meetings with future partner companies, it was possible to have a first understanding of how and when CNs are established as well as how the selection process of partner companies happens.

The data collection for the exploratory study involved two main steps. First, the researcher performed unstructured interviews with managers of the different departments of the Developer Company, and collected documents and reports about the NSD process. The documents and reports contained important information about the NSD process.

In the exploratory study, the meetings for selection process of the CNs partner companies were recorded and literally transcribed and with the support of NVivo software. Therefore, using the NVivo software, the collected data were categorized according to main objectives of the exploratory study. The reports and documents were analyzed in detail through Content Analysis 
Technique (VALENTIM, 2005) and classified by NSD stages and CNs quality factors. The results provided insights that served as basis to start the Qualitative Study. However, the exploratory study did not identify the $\mathrm{CN}$ quality factors, as well as how these factors influence the NSD Performance.

Therefore, the Qualitative Study aimed to identify the quality factors of the $\mathrm{CN}$ and how they change along its different stages. The study also addressed CNs quality factors that become important for NSD performance. This study represented an important stage of this research, once it allowed an in-depth understanding of the phenomenon under study: New service development process in the collaborative networks context.

In this qualitative study, 39 interviews (totalized 29 hours during a period of 12 months) were conducted with managers of the Developer Company and partner companies directly involved in the NSD process. The interviews were made across the different stages of the NSD process and covered both Developer Company and partners on each stage. This sample design aimed at maximizing relevant variability for a rich analysis of the phenomenon and saturation.

The interviews were recorded, literally transcribed and analyzed with the support of the NVivo software. However other sources for data collection were used: documents given by partner companies such as contracts; reports and manuals; analysis of information and knowledge management platform used by Developer Company managers.

The answers to the interviews were analyzed through open coding, that is, the contents were evaluated according to categories or classes of indicators/factors based on research objectives. At this stage, the qualitative analysis software NVivo was used to codify and categorized the data collected for subsequent data analysis.

\section{Results}

\section{Evolving of the collaborative networks along NSD process stages}

The exploratory multiple case study allowed us to better understand which are activities and stages that comprise the NSD process as well as the role of the CN along NSD process stages. The exploratory study results showed that the process of NSD in the four complex projects followed a cyclical pattern. This means the process of developing new services does not end, but is constantly evolving.

Based on results, four main stages were identified in the NSD process cycle: idea generation and conceptual project development (both stages are defined as early stages); construction; launch; and operation. In each single stage different networks are established, as can see in Figure 1. However, the study results revealed that after the service is launched and the operation stage begins, the process doesn't stop.

The results allowed us to better understand which are activities as well as, why the networks are established along NSD stages. Each stage of the NSD process has the participation of the different external partners and departments of the Developer Company, due to its complexity. The constant changing of the team in all NSD stages happens given to the different characteristics, particularities and activities engaged in every single stage. It is interesting to note that none of the members, whether internal or external, was directly involved in the entire NSD process, that is, even the project managers and external suppliers change along the different stages.

The idea generation for a new service is the departure point to the NSD process. The idea generation is the systematic and continuous search for new service opportunities, as without new ideas there are not new services to develop. The main objective of the Idea Generation stage is to develop a new idea for a new service or improve an existing service. 


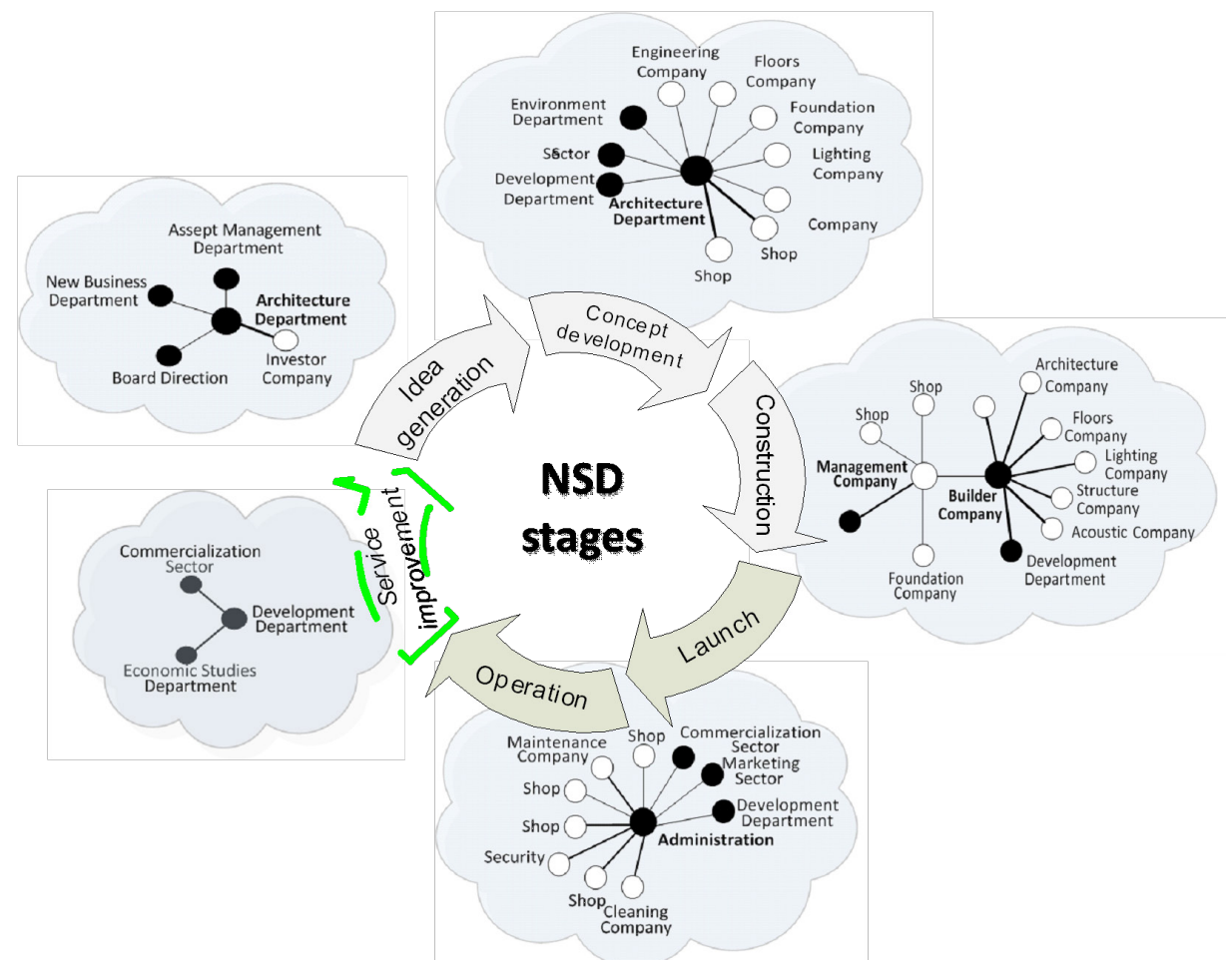

Legend: Developer Companies; $\bigcirc$ partner Companies; — Strong relationship; — Weak relationship.

Source: the autor.

NSD idea generation stage follows a set of activities and processes previously established. These activities are developed mostly internally through different departments of the Developer Company, which is the service owner.

This way, the number of partnerships is small or inexistent, since this stage involves activities of the "core business" of the Developer Company. The team that develops this stage is composed by experts, that corroborates Edvardsson's findings (2000), which highlight the importance of having specialized and multidisciplinary teams in the NSD process.

These results reveal that this stage is the beginning of all the NSD process and the generated information will serve as the basis for the development of the following stages. This stage therefore influences all subsequent stages of the NSD process, with a significant impact on NSD performance success.

The objective of conceptual development Stage is to transform the new service idea (intangible concept) into a tangible concept, with concrete specifications of the new service proposal, describing the value proposition the company wants to offer to future clients.

The activities involved to develop the service concept, that is, the definition of the core offering are carried out "in house" without interventions of the external partners. These activities are: study of the market trends; study of the characteristics of the potential customers; analysis of the characteristics of the region where the service will be offered, study of the services that are already offered in the same region by potential competitors definition of the geographical location; and definition of the conceptual design of the new service.

The Developer Company, of a new service endeavours, to develop its core concept, delegating other activities of this stage to partner companies through strategic outsourcing.

The collaborative relationship with external companies since the early stages of NSD process 
provides a reduction in time and cost of the process. This first $\mathrm{CN}$ is formed by partner companies with the aim of executing the activities that were defined by the Developer Company around the central concept of the new service, as the Developer Company is not able or it is too costly to develop these activities internally.

On the one hand, these partner companies are expert in several activities that are necessary to develop the service concept in a complete way. On the other hand, the core service concept is internally created by the Developer Company, to preserve strategic knowledge and core competencies that are crucial for sustaining the company's competitive advantage.

Construction Stage involves the construction of the physical space where the service will be offered. This stage defines important physical attributes for the customer's perception regarding future service quality. The construction builds upon the information of the conceptual projects already pre-defined in early stages.

The main activities which composed this NSD process stage are: executive projects development, from architecture to air conditioning projects, among others (as already mentioned, these projects varied according to the service type which the company is going to offer); new service marketing activities; and commercialization. The management of the physical evidences, such as, equipments, signalization, furnishing, environment smell and temperature and so on, positively influence the customer experience along the service meeting.

Although these activities are developed by Developer Company's departments such as marketing and commercialization, in this construction stage a new $\mathrm{CN}$ is formed with new companies specialized in the executive projects area. Therefore, new partnerships are established with construction companies, which are going to build everything that was defined in the concept development stage.
The launch stage of the new service has two moments. The first moment is related to the service launch for partner companies and the second moment is associated to the service launch to the public/customers.

\section{Service launch for partner companies}

This first moment is related to the service launch for the partner companies, which will offer the supplementary services, that is, those services that add value to the core service offering, such as store retailers.

In this moment new relationships are formed between partner companies in the $\mathrm{CN}$ context and are characterized by long-term contracts due to the high investments made by these partners into the mall. These partners are mostly store retailers responsible for offering the important supplementary services. Relationships with these partners are strong, as they play a key role in attracting customers and adding value to the core service.

\section{Service launch for the customers}

The second moment involves the launch of the new service to the market, that is, for the public/ customers. All the service components, such as workers, functional structures, supplementary services, physical spaces, technical systems and processes must be ready. These components need to form a harmonically set and work together to guarantee that the service launch to the public is a success and operationally effective. Therefore, it is important for the service system to guarantee the necessary resources to enable the new service delivery process.

A new and extensive $\mathrm{CN}$ is formed and new relationships are established with new partner companies. These companies are responsible for the new service management and maintenance, after being launched to the public. The management and maintenance of the new service involve activities such as: cleaning, technical equipments maintenance (air-conditioning, 
elevators, escalators, surveillance cameras), recycling among others.

For these activities performance, new relationships are established with other companies in the $\mathrm{CN}$ context. This new $\mathrm{CN}$ involves rendered service companies related to the before mentioned activities. These activities are crucial for the service quality and for the first good impression of the service by the customer.

In this stage, it is also necessary to recruit and select the workers that will be part of the service in operation and that will develop different functions, so that the new service objectives will be achieved and guarantee the customer satisfaction.

Service operation is considered a stage of the NSD process, as the NSD is a constant cycle of activities, in a cyclical process (JOHNSON; MENOR et al., 2000). Some researchers define this stage as "the moment of truth" (EDVARDSSON; GUSTAFSSON et al., 2000; GRONROOS, 2000; FROEHLE; ROTH, 2007), that is, the moment when the customers will consume the service, and the work from previous stages comes to life. The results of the operation stage are influenced by the customer participation, and some characteristics such as: security, comfort, leisure or cleaning, become essential requirements for customer satisfaction.

This process stage is influenced by several factors to the organization, which are not so relevant until then. Some these factors are those brought by the market where the service is being offered, such as: trends, culture, local customer characteristics and local competitors. These factors, as well as how they influence the performance of the service when operating, cannot be totally previewed in the previous stages of the development process. This happens because these factors are unknown and occur randomly at the moment of the service offer. Sometimes the urge to launch the new service in the market (JOHNE; STOREY, 1998) increases even more this lack of knowledge about some factors which influence service operation performance.
The management of these factors as well as all the service operation is the Developer Company's service responsibility. A management expert team remains constantly in a backstage area and consists of people who occupy positions from Operational and Marketing Manager, to the General Manager.

At this stage, the objective is to coordinate the demanded activities and processes to cocreate value with the customer. Therefore, the main activities involved on the complex service management when operating involve delivery activities and new service consumption for the customers, such as: management of the technical operations; the partner companies' management; partner retailer's management; and marketing activities.

At this stage, although some relationships remain from the previous stage, new partnerships are established with companies from different sectors to perform the service maintenance such as: elevators and escalators maintenance companies, air conditioning and electricity, recycling companies, cleaning among others and new partnerships is established with retailers. Depending on the type and characteristics of the service these partnerships can change.

The partnerships in this stage are characterized by temporary contracts characterizing the supply chain, such as: cleaning, security, maintenance among others, in which rights, rules and duties of both parts are described (the Developer Company and contracted one). There are also long time contracts with smaller store retailers that offer the supplementary services.

Once customer needs and market trends change fast, the service is constantly evaluated by the Developer Company and in a near future the service should be adapted to these new needs. Therefore, the Developer Company was already conducting a new market research in order to improve the services due to the changing needs of customers. This shows that the process of NSD is a constant cycle and has does not end once it is 
launched in the market (JOHNSON; MENOR et al., 2000).

\section{NSD in the CN context}

The companies are always looking for service improvements that involve an evaluation of the service being provided and an evolution to keep up with new market trends and changes in customer needs. On the one hand, the exploratory study revealed that each NSD process stage is developed by different departments of the Developer Company and different partners companies. However, the participation of these companies evolves along all NSD stages.

On the other hand, the qualitative study showed that CNs play an important role in the NSD process, once it is very difficult for a single company to posses in house all competences needed to develop these activities in the best way. The results reveled that the Developer Company develops the activities of its core business, while establishing partnerships for the activities considered secondary.

The collaborative relationship through the CNs since the early stages of NSD provides a reduction in its time and cost, potentiates the process once some activities are developed by specialists companies. Therefore, the results show that $\mathrm{CNs}$ play an important role in complex NSD projects, once they are responsible for the execution of several important activities along the different NSD stages. However, simply creating a $\mathrm{CN}$ is not enough.

The quality of the $\mathrm{CN}$ determines the positive or negative impact it will have on NSD performance. CNs quality factors that drive NSD performance are categorized into two dimensions: (1st) Partner characteristics and (2nd) Relationship characteristics.

\section{CNs Quality - Partner characteristics}

Partner characteristics are related to the attributes that the partner companies should have to successfully participate in the $\mathrm{CN}$ in a complex NSD project. Partnership experience, Know-how, Compliance with contract and norms, Brand reputation, flexibility and sustainability focus were pointed out as desirable characteristics that partner companies should specifically have to contribute to the NSD performance success. These and other dimensions of CNs Partner characteristics are shown in Table 1.

Table 1 - CNs Partner Characteristics

\begin{tabular}{lc}
\hline CNs Partner Characteristics & $\begin{array}{c}\text { Overall } \\
(\mathrm{n}=39)\end{array}$ \\
\hline Partnership Experience & $74 \%$ \\
Know-how & $64 \%$ \\
Compliance with contract and norms & $64 \%$ \\
Brand reputation & $59 \%$ \\
Flexibility & $51 \%$ \\
Sustainability Focus & $49 \%$ \\
Innovation focus & $49 \%$ \\
Service quality & $46 \%$ \\
Proactiveness & $44 \%$ \\
Compatibility of process & $39 \%$ \\
Customer Focus & $38 \%$ \\
\hline
\end{tabular}

Source: developed by author based on Research data.

Partner characteristics that compose the $\mathrm{CNs}$ are very important once $\mathrm{CNs}$ partners are responsible for developing the activities related to complex NSD projects, and their performance has a direct influence in the project performance success.

Partnership Experience is related to the partners' previous experience working together through $\mathrm{CNs}$ or other type of collaboration between companies to develop products and services. The experience in previous projects strengthens the network relationship and enables the resolution of possible conflicts when executing any activities of the NSD process, due to past experience on previous projects that may serve as "examples" for new project development.

Companies which have previous partnership experience have a stronger capability of managing both internal and human resources, making it easier to solve possible conflicts that may occur 
along the networks relationship (ANAND; KHANNA, 2004).

In this line, Know-How also was pointed out as an important characteristic that partner companies should satisfy to potentiate NSD process success. From the interviewees' point of view, know-how involves the knowledge that the company where they work has in a specify area, and they believe that their company is better than the competitors. For them, this knowledge is the reason why their company is selected to work in a CN in the NSD process. According to a retail store manager of the launch stage:

[...] the first Mall was a success, but nowadays in Portugal there are too many Shopping Malls. What happens is that the Developer Company has success for its experience and know how in developing Shopping Malls. Where they operate there's always success.

Therefore, the companies which possess knowhow are seen as valuable partners in the NSD projects, once the know-how constructs a strong competitive advantage that potentiates these projects. In this context, is inferred that Knowhow has a strong impact on NSD performance, once partner companies have specific knowledge about determined activities, and help to optimize the process development and final service success.

In the complex NSD projects context, in addition to Kwon-How and partnership experience, Compliance with contract and norms also was identified as an important characteristic to NSD performance. Such characteristic is extremely important to work in the network context, once there are many companies working at the same time in the same project; as such, respecting the rules established by contracts is more critical than if the company worked alone.

This factor assumes an essential role to develop a structured coordination of the NSD process and to achieve some NSD goals, such as project deadlines, so that the new service is created in harmony and in the planed time. According to a Retail store manager of the launch stage:
[...] the strong and active management of the Mall's space is what makes the Developer Company obtain success in its Shopping Malls. It is to me what dictates the success of everything. The managers do not stay still, they do not let the space get damaged, that is, they follow all the strictness, rules and contracts and are examples for the partners.

It is very important that companies comply with standards and rules that are pre-established in the partnership contract, because in this way, is possible to ensure: respect between all partners involved in network; that all activities of the NSD process are developed within standards and legal requirements; quality and efficiency in the development of the activities involved on process; transparency in management of the $\mathrm{CN}$; and solution of possible problems surrounding the NSD process.

Companies of large dimension have preestablished policies that involves standards and rules given to complexity of their activities as well as their image in the market. This way, Brand Reputation is related to the company reputation in the market where it is inserted and is a very important characteristic for NSD Performance, especially when the service is released to the final customer.

On the one hand, companies with good market reputation have more possibility to establish partnerships, once their work is already known by both customers and competitors. On the other hand for the less known brands, this factor is also important, as they benefit from sharing the same space with well-known brands.

In addition to all quality factors mentioned at the moment partner companies should be flexible, given the complexity involved in the NSD process and the vicissitude of market trends. Companies need to have flexibility to adapt themselves to process changes.

Flexibility is related to the capability of partners to adapt their process to respond to both market and customer trends and NSD process modifications. 
NSD requires many changes throughout the process and for this reason partner companies should be able to adapt their activities and processes quickly to cope with those changes.

Complex NSD projects are developed into a long time due to several activities and tasks that are involved in the project. These activities are very complex, given the large dimension of a NSD process of the shopping mall type. Therefore, these projects tend to generate more residual which can cause environmental impact than projects with a less dimension. In this context, Sustainability is therefore another important factor mentioned by both of the Developer Company and CNs partners interviews, which is related to self-sustainable processes and environmentally friendliness.

This factor crosscuts the different stages of the NSD process, and all companies working in CNs need to undertake their processes taking into account environmental preservation, so the new service becomes sustainable from the start.

In this line, Innovativeness was also considered a key characteristic for a partner that work in the CNs for NSD, once the customer needs, market trends and technology are constantly changing, and this requires constant investment in innovation from the companies. Innovative companies are those able to constantly develop new ideas the NSD project, or to improve the NSD process.

The focus on innovation has the ability to add value to the NSD process, distinguishing it in the competitive landscape in which the new service is introduced. Companies that innovate in services and products, process or business models, either in an incremental or radical way, are at an advantage over other competitors.

In this line, other two important characteristics of partner companies were pointed out by interviewees, which can also be associated with innovativeness: quality of the renderer service and the customer focus. Both characteristics complete each other once the service quality depends on the ability of the company to focus on customers and offer services that suit their needs. According to the retail store's manager of the launch stage:

[...] we have the conditions to offer a complete mall service, because we know the market, and we execute and supply all our services focusing on the customer. We have the know-how and knowledge to serve in an excellent way in any place in Brazil and this is translated in a complete service of high.

The quality of the service renderer and the focus on customer needs by every partner strongly impacts NSD final success.

In complex NSD projects a $\mathrm{CN}$ is composed by several partner companies that are responsible for developing of several activities. In this context, due to the large number of the partners working in the same time, problems and conflicts becomes inevitable. Therefore, these partners should be able to propose improvements and solutions quickly in order to not influence in a negative way the NSD performance, that is, $\mathrm{CN}$ partner companies should be proactive during all NSD process.

In this line, Pro-activity is an important factor that influences the choice between one and other partner company. Pro-activity involves the capacity of the companies to propose solutions and take initiatives to solve problems. Proactive companies are agile and have a quick capacity to propose solutions to solve unexpected problems.

Proactive companies are more indicated to be partners in complex NSD projects once, as already mentioned, the NSD process involves several changes along all the process and these changes should be solved in a creative, innovative and fast way.

In this context, once that NSD process involves several changes and there are many companies involved in a network to develop new services, companies that have the process compatibility can help to create a new service of the fast way. This characteristic indicates that partner companies should have systems, structures and processes 
minimally compatible to work in the same NSD project.

Compatibility in the process between partners is crucial for partners to work together in a productive way with a clear orientation to results, which in this case is NSD success. Thus, companies with consistent processes and documentation are conducive to business partnerships.

It is important highlights, that some of the partner characteristics mentioned such as: partnership experience, compliance with contract and norms, flexibility and compatibility of process are considered very important before establishing a relationship in the network, once they can cause disagreement between the participant companies, and thus influence the NSD process.

Therefore, when the Developer Company selects a partner to compose the CNs for complex NSD projects, it becomes necessary to analyze if that partner has at least some of these characteristics. These partner quality factors are therefore a set of pre-conditions for a successful $\mathrm{CN}$ and a successful NSD project to happen.

\section{CNs Quality - Relationship characteristics}

The Relationship characteristics involve the attributes that classify a good network relationship between partner companies that work in the CN of the complex NSD projects. The Table 2 shows the $\mathrm{CN}$ relationship characteristics, comprising mutual learning, trust, company's image improvement, communication and shared vision.

Table 2 - CNs Relationship Characteristics

\begin{tabular}{lc}
\hline Relationships Characteristics & $\begin{array}{c}\text { Overall } \\
(\mathrm{n}=39)\end{array}$ \\
\hline Mutual Learning & $69 \%$ \\
Trust & $62 \%$ \\
Company's image improvement & $56 \%$ \\
Communication & $54 \%$ \\
Shared vision & $49 \%$ \\
\hline
\end{tabular}

Source: developed by author based on Research data.
Once that the $\mathrm{CN}$ is a set of independent organizations that collaborate between themselves, through the provision of goods and services in order to achieve common objectives (LEWIS, 1992; ROSENFELD, 1997; CAMARINHA-MATOS; AFSARMANESH, 2008), mutual learning ends up to be a natural process in the cooperation between companies in a network, once the information and knowledge exchange between the partners can influence NSD Performance.

Mutual Learning involves the capacity of CN partners that work in complex NSD projects to acquire new knowledge by contacting and learning from other partners and being to apply such knowledge in their daily routine.

As already mentioned, a complex NSD project such as the development of a shopping mall involves several organizations in the $\mathrm{CN}$ context with different goals and processes across different NSD stages. Therefore, besides to the mutual learning, trust between all the partners involved becomes a relevant factor for the success of a relationship in network.

However, to establish and maintain trust in the $\mathrm{CN}$ is a challenging aspect due to the number of companies involved and the fact that each single company has different perspectives and visions about the same problem. This result is consistent to what has been highlighted by Whipple and Frankel (2000), who stated that in NSD projects trust is crucial for the relationship once each partner depends on the other to achieve its own activities and goals in the best way (WHIPPLE; FRANKEL, 2000).

Trust is more relevant in the relationships with external companies than between the departments of the same company, once managers from the partner companies are more independent and the Developer Company does not have a direct control on the activities they developed.

In this line, once that in the network there are several companies working together and in the same time - company's image improvement 
becomes a relevant characteristic. Company's image improvement involves the influence that a company's brand has on their partners when they are networked. For example, if a small company establishes a partnership with a big company that is already very famous in the market and has a strong credibility, it is very likely that the smaller company becomes better known, and customers end up associating its image to the one of the big company.

This characteristic becomes relevant in complex NSD projects, because they involves a higher number of partnerships, and the probability of establishing partnership with well-known companies, improving the image of a new service is higher than in a smaller dimension project.

In a network relationship, communication as well as information flow between all partners is of extreme importance for relationship success. The network manager should be apt to use the information and regularly disseminate the information to all companies involved in the network, in order to generate value aiming at relationship success (YOSHINO, 1996).

A strong and structured communication was emphasized by interviewees as essential to a successful $\mathrm{CN}$ relationship. A structured communication between all the companies involved in the CNs allows all the companies to work in the same direction, focusing efforts to achieve the same goals. Communication is also the base to create trust and to develop a shared vision about the service concept.

Shared vision means that all partners engaged in the process of developing the new service should share a common vision of the service being developed. A shared vision enables the $\mathrm{CN}$ and the NSD project to develop in harmony, by defining a common set of achievable goals.

In this context, for the NSD process to occur in the best shape and the final service to be a success, its partners must share the same vision about the concept of service/product they are developing. If there is no total similarity in sharing this view, there should be efforts to ensure that there are at least complementary.

To sum up, the CN quality factors represent some characteristics that the $\mathrm{CN}$ partner companies should have in the complex NSD projects context. The study results show, that these quality factors are divided in two dimensions: $\mathrm{CN}$ partners characteristics and $\mathrm{CN}$ relationship characteristics. The partner characteristics that more influence the NSD Performance are Partnership Experience, Know-how, Compliance with contract and norms, Brand reputation, Flexibility, Sustainability Focus, Innovation focus, Service quality, Proactiveness, Compatibility of process and Customer Focus. From the interviewees' point-of-views, these characteristics might influence the good development of the activities and tasks involved in the complex NSD projects and consequently influence NSD Performance.

The study showed that some quality factors crosscut all stages of NSD, however, the relevance of these factors evolves along these different stages. Other factors are specific of each single NSD stage. These results contribute for integrating CNs and NSD research to cope with the new challenges of complex NSD projects. This study also brings new insights on how the management of CNs should evolve through the different stages of the NSD process in order to enable its success.

\section{Discussions and conclusions}

The study showed that new forms of collaboration between partner companies happen more often to potentiate the NSD process, specially, in complex NSD projects as these services need multiple competences which a stand-alone company cannot possess in house.

Due to the specificity and complexity of the activities necessary to manage these different stages of the NSD process, the collaboration between companies in the Collaborative Networks context is increasingly adopted. 
In complex NSD projects, network management requires a relationship with values, ideas and trust exchange, which can build a strong commitment among all partners involved in the CNs, enhancing NSD performance and final service success. Therefore, this study contributes to understand the NSD process, which is characterized by different stages: Idea generation and concept development (early stages), Construction, Launch and Operation Stages.

Along all NSD stages, the main forms of the collaborative relationships are Strategic Partnerships and Supply Chain. These two types of relationship are classified by characteristics of the contract as well as by the degree of participation of these partners along the NSD process.

The results showed that CNs quality factors are classified through two dimensions: $\mathrm{CN}$ partner characteristics and $\mathrm{CN}$ relationship characteristics.

The desirable characteristics that $\mathrm{CN}$ partner should specifically have are: partnership experience; know-how; flexibility; and sustainability focus. The main characteristics that indicate the quality of the CN Relationship between partner companies are: mutual learning; common vision; and trust.

These characteristics were pointed out as crucial and have a great influence to the NSD performance. These results are very important for the good development of complex NSD projects, once they minimize the conflicts and enable an evolution of a successful NSD process.

Based on all the exposed, the exploratory and qualitative studies made important contributions to a better understanding of the influence of the CNs Quality on NSD performance. All studies supported the idea that networks are more frequently used in complex NSD projects and the CNs Quality becomes essential to complex NSD projects performance success and by consequence the final service success.
These contributions help in order to integrate CNs and NSD research streams to cope with the new challenges of complex NSD projects. This study also brings new insights about how the management of CNs should evolve through the different stages of the NSD process to enable its success.

To add up, the results indicate that the network management is very important due to the intense interactions that happen between the partner companies along all NSD process. The Developer Company, as the owner service, is responsible for the $\mathrm{CN}$ management and should face this task with extreme care.

Establishing processes that guarantee an effective relationship management, as well as a good communication between all parts involved in different CNs along NSD stages, can assure a better operational effectiveness and by consequence improve NSD performance and the success in the service launch.

The results show that $\mathrm{CN}$ Quality as well as the actions and activities developed by the $\mathrm{CN}$ partner companies have a great impact on the performance of complex NSD projects. Therefore, the CNs management is an important aspect to achieve the excellence in performance in complex NSD projects.

This study approached just one NSD project type, which was the Shopping Mall. For further researches, this could be expanded not only for other sectors but also for other types of projects. This because, new researches, about NSD performance and CN Quality, if studied in new scenarios, besides being analyzed in new contexts, could be confirmed, applied and adapted to new realities, which could involve not only service projects, but also product projects.

Therefore, for further researches, it is suggested to involve not only companies which are part in NSD process, but also the final customers, as these are also part of the NSD process and the service final success depends as well on the interaction 
and experience of these customers throughout the offer and consumption of the service.

\section{References}

AKAMAVI, R. K. A research agenda for investigation of product innovation in the financial services sector. Journal of Services Marketing, v. 19, n. 6, p. 359-378, 2005. Disponível em: <http://dx.doi. org/10.1108/08876040510620148>. Acesso em: 18 out. 2012.

ALAM, I.; PERRY, C. A customer-oriented new service development process. Journal of Services Marketing, v. 16, n. 6, p. 515-534, 2002. Disponível em: <http:// dx.doi.org/10.1108/08876040210443391>. Acesso em: 18 out. 2012.

ALBRECHT, K. Revolução nos serviços: como as empresas podem revolucionar a maneira de tratar os seus clientes. São Paulo: Pioneira, 2000.

ANAND, B. N.; KHANNA, T. Do firms learn to create value? The case of alliances. Strategic alliances: theory and evidence. Strategic Management Journal, v. 21, n. 3, p. 295-316, 2004. Disponível em: <http://dx.doi. org/ 10.1002/(SICI)1097-0266(200003)21:3<295::AIDSMJ91>3.0.CO;2-O> . Acesso em: 18 out. 2012.

AUSTIN, J. E. The collaboration challenge: how nonprofits and businesses succeed through strategic alliances. New York: Jossey-Bass, 2000.

CAMARINHA-MATOS, L.M.; AFSARMANESH, H. Collaborative networks : reference modeling. New York: Springer, 2008.

CAMARINHA-MATOS, L. M.; AFSARMANESH, H. Collaborative networks: a new scientific discipline. Journal of Intelligent Manufacturing, v. 16, n. 4, p. 439-452, 2005. Disponível em: <http://dx.doi. org/10.1007/s10845-005-1656-3>. Acesso em: 18 out. 2012.

CHARMAZ, K. Constructing grounded theory: a practical guide through qualitative analysis. Sage Publications: Thousand Oaks, 2006.

CHEN, J.-S.; TSOU, H.-T. ;CHING,R.K.H. Co-production and its effects on service innovation. Industrial Marketing Management, v. 40, n. 8, p. 1331-1346, nov. 2011. Disponível em: <http://dx.doi.org/10.1016/j. indmarman.2011.03.001>. Acesso em: 18 out. 2012.

COOPER, R.; EASINGWOOD, C. et al. What distinguishes the top performing new products in financial services. Journal of Product Innovation
Management, v. 11, n. 4, p. 281-299, 1994. Disponível em: <http://www.sciencedirect.com/science/article/ pii/0737678294900841>. Acesso em: 18 out. 2012.

DE BRENTANI, U. Success and failure in new industrial services. Journal of Product Innovation Management, v. 6, n. 4, p. 239-258, 1989. Disponível em: <http://dx.doi.org/10.1016/0737-6782(89)900775>. Acesso em: 18 out. 2012.

DE BRENTANI, U. Success factors in developing new business services. European Journal of Marketing, v. 25, n. 2, p. 33-59, 1991. Disponível em: <http://dx.doi. org/10.1108/03090569110138202>. Acesso em: 18 out. 2012.

\section{DENZIN, N. K.; LINCOLN, Y.S. (Ed.). The SAGE} handbook of qualitative research. 3rd ed. London: Sage Publications, 2000. Acesso em: 18 out. 2012.

EDGETT, S. The traits of successful New Service Development. Journal of Services Marketing, v. 8, n. 3, p. 40-49, 1994. Disponível em: <http://dx.doi. org/10.1108/08876049410065606>. Acesso em: 18 out. 2012.

EDVARDSSON, B.; GUSTAFSSON, A. et al. New service development and innovation in the new economy. Lund: Studentlitteratur, 2000.

EDVARDSSON, B.; A. GUSTAFSSON, A.; ROOS, I. Service portraits in service research: a critical review. International Journal of Service Industry Management, v. 16, n. 1, p. 107-121, 2005. Disponível em: <http://dx.doi.org/10.1108/09564230510587177>. Acesso em: 18 out. 2012.

FITZSIMMONS, J.; FITZSIMMONS, M. Service management: operations, strategy, and information technology. Hardcover: Irwin Professional, 2001.

FROEHLE, C. M.; ROTH, A.V.; CHASE, R. B.; VOSS, C. A. Antecedents of new service development effectiveness: an exploratory examination of strategic operations choices. Journal of Service Research, v.3, n.1, p. 3-7, 2000. Disponível em: <http://dx.doi. org/10.1177/109467050031001>. Acesso em: 18 out. 2012.

FROEHLE, C. M.; ROTH, A. V. A resource process framework of new service development. Production and Operations Management, v. 16, n. 2, p. 169-188, 2007. 
GRONROOS, C. Creating a relationship dialogue: communication, interaction and value. The Marketing Review, v. 1, n. 1, p. 5-14, 2000. Disponível em: <http://dx.doi.org/10.1362/1469347002523428>. Acesso em: 18 out. 2012.

HÅKANSSON, H.; SNEHOTA, I. No business is an island: the network concept of business strategy. Scandinavian Journal of Management, v. 5, n. 3, p. 187-200, 1989. Disponível em: <http://dx.doi. org/10.1016/0956-5221(89)90026-2>. Acesso em: 18 out. 2012.

JOHNE, A.; STOREY, C. New service development: a review of the literature and annotated bibliography. European Journal of Marketing, v. 32, n. 3/4, p. 184-251, 1998. Disponível em: <http://dx.doi. org/10.1108/03090569810204526>. Acesso em: 18 out. 2012 .

JOHNSON, G.; SCHOLES, K.; WHITTINGTON, R. Explorando a estratégia corporativa: texto e casos. São Paulo: Bookman, 2007.

JOHNSON, S. P.; MENOR, L. J.; ROTH, A. V.; CHASE, R. B. A critical evaluation of the new service development process: integrating service innovation and service design. In: FITZSIMMONS, J.; FITZSIMMONS, M. (Ed.). New Service Development: creating memorable experiences. Thousand Oaks: Sage Publications, 2000. p. 1-32.

KELLY, D.; STOREY, C. New service development: initiation strategies. Library Consortium Management: an International Journal, v. 2, n. 5/6, p. 104-122, 2000. Disponível em: <http://dx.doi. org/10.1108/14662760010800784>. Acesso em: 18 out. 2012.

LEWIS, J. D. Alianças estratégicas: estruturando e administrando parcerias para o aumento da lucratividade. São Paulo: Pioneira, 1992.

LUSCH, R. F.; VARGO, S. L.; TANNIRU, M. Service, value networks and learning. Journal of the Academy of Marketing Science, v. 38, n. 1, p. 19-31, 2010. Disponível em: <http://dx.doi.org/10.1007/s11747008-0131-z>. Acesso em: 18 out. 2012.

MARTIN, C.; HORNE, D.; SCHULTZ, A. M. The business-to-business customer in the service innovation process. European Journal of Innovation Management, v. 2, n. 2, p. 55-62, 1999. Disponível em: <http://dx.doi.org/10.1108/14601069910269772>. Acesso em: 18 out. 2012.

MENOR, L. J.; TATIKONDA, M.; SAMPSON, S. E. New service development: areas for exploitation and exploration. Journal of Operations Management, v. 20, n. 2, p. 135-157, abr. 2002. Disponível em: <http:// dx.doi.org/10.1016/S0272-6963(01)00091-2>. Acesso em: 18 out. 2012 .

OJANEN, V.; LANNE, M.; REUNANEN, M.; KORTELAINEN, H.; KÄSSI, T. New Service Development: success factors from the Viewpoint of Fleet Asset Management of Industrial Service Providers. In: INTERNATIONAL WORKING SEMINAR OF PRODUCTION ECONOMICS, 15. 2008, Innsbruck, Austria. Pre-prints... mar. 2008, p. 369-380. Disponível em: <http://virtual.vtt.fi/virtual/ proj3/FleetAM/ojanen_etal-innsbruck.pdf>. Acesso em: 18 out. 2012.

OSTROM, A. L.; BITNER, M. J.; BROWN, S. W.; BURKHARD, K. A.; GOUL, M.; SMITH-DANIELS, V.; DEMIRKAN, H.; RABINOVICH, E. Moving forward and making a difference: research priorities for the science of service. Journal of Service Research, v. 13, n. 1, p. 4-36, 2010. Disponível em: <http://dx.doi. org/10.1177/1094670509357611>. Acesso em: 18 out. 2012.

OTTENBACHER, M.; GNOTH, J.; JONES, P. Identifying determinants of success in development of new high-contact services: Insights from the hospitality industry. International Journal of Service Industry Management, v. 17, n. 4, p. 344-363, 2006. Disponível em: <http://dx.doi.org/10.1108/09564230610680659>. Acesso em: 18 out. 2012.

REIDENBACH, R.; MOAK, D. Exploring retail bank performance and new product development: a profile of industry practice. Journal of Product Innovation Management, v. 3, n. 3, p. 187-194, 1986. Disponível em: <http://dx.doi.org/10.1111/1540-5885.330187>. Acesso em: 18 out. 2012.

ROSENFELD, S. A. Bringing Business Clusters into the mainstream of economic development. European Planning Studies, v. 5, n. 1, p. 3-23, 1997. Disponível em: <http://dx.doi.org/10.1080/09654319708720381>. Acesso em: 18 out. 2012.

SCHEUING, E.; JOHNSON, E. A proposed model for new service development. Journal of Services Marketing, v. 3, n. 2, p. 25-34, 1993. Disponível em: <http://dx.doi. org/10.1108/EUM0000000002484>. Acesso em: 18 out. 2012.

STEVENS, E.; DIMITRIADIS, S. Managing the new service development process: towards a systemic model. European Journal of Marketing, v. 39, n. 1/2, p. 175-198, 2005. Disponível em: <http://dx.doi. org/10.1108/03090560510572070>. Acesso em: 18 out. 2012. 
SUNDBO, J. Management of innovation in service. The Service Industries Journal, v. 17, n. 3, p. 432-445, 1997. Disponível em: <http://dx.doi. org/10.1080/02642069700000028>. Acesso em: 18 out. 2012.

SYSON, F.; PERKS, H. New service development: a network perspective. Journal of Services Marketing, v. 18, n. 4, p. 255-266, 2004. Disponível em: <http:// dx.doi.org/10.1108/08876040410542254>. Acesso em: 18 out. 2012.

TAX, S.; STUART, I. Designing and implementing new services: the challenges of integrating service systems. Journal of Retailing, v. 73, n. 1, p. 105-134, 1997. Disponível em: <http://dx.doi.org/10.1016/S00224359(97)90017-8>. Acesso em: 18 out. 2012.

TETHER, B. S.; TAJAR, A. The organizationalcooperation mode of innovation and its prominence amongst European service firms. Research Policy, v. 37, n. 4, p. 720-739, 2008. Disponível em: <http:// dx.doi.org/10.1016/j.respol.2008.01.005>. Acesso em: 18 out. 2012.

VALENTIM, M. L. P. Métodos qualitativos de pesquisa em Ciência da Informação. São Paulo: Polis, 2005.

VALKEAPAA, E. et al. New service development process in a strategic alliance. In: INTERNATIONAL PRODUCT DEVELOPMENT MANAGEMENT CONFERENCE, 13., 2006. Proceedings... Milano. p. 1487-1501, 2006.

WHIPPLE, J. M.; FRANKEL, R. Strategic alliance success factors. Journal of Supply Chain Management, v. 36, n. 3, p. 21-28, 2000. Disponível em: <http://dx.doi. org/10.1111/j.1745-493X.2000.tb00248.x>. Acesso em: 18 out. 2012.

YOSHINO, M. Y. Strategic alliances: an entrepreneurial approach to globalization. Harvard: Business School Press, 1996.
Uma visão do processo de inovação numa perspectiva colaborativa

\section{Resumo}

Introdução: A Inovação e o processo de desenvolvimento de novos serviços têm mudado nos últimos anos. Atualmente se aceita que este processo ocorre em quatro fases genéricas desde a geração da ideia do novo serviço até sua implantação. Nestas fases, alguns fatores são reconhecidos como importantes e, dada sua complexidade, o processo de desenvolvimento de novos serviços por uma única empresa pode ser facilitado pelo relacionamento com empresas parceiras. A investigação objetivou verificar o grau de influência das redes colaborativas no desempenho do processo de desenvolvimento de novos serviços. Método: Estudo exploratório de múltiplos casos e estudo qualitativo. Resultados: Alguns fatores são comuns em todo o processo de desenvolvimento de novos serviços. Porém, a relevância destes se altera ao longo das diferentes fases. Conclusão: Os fatores de qualidade das redes colaborativas que contribuem para o desempenho do processo podem ser classificados em duas dimensões: a primeira, voltada para as características das parceiras e, a segunda, para as caracteristicas do relacionamento.

\section{Palavras-chave}

Inovação em serviços. Processos de inovação. Desenvolvimento de serviços. Redes colaborativas.

\section{Acknowledgments:}

Fundação para a Ciência e Tecnologia - FCT.

Received 3 September 2012

Accepted 3 October 2012

\section{About the author:}

\section{Thais B. Zaninelli}

Bacharel em Biblioteconomia - Universidade Estadual de Londrina (UEL), Mestre em Gestão de Informação Universidade do Porto (UP/Portugal), Doutora em Engenharia Industrial e Gestão - Universidade do Porto (UP/Portugal). tbz@uel.br

How to cite this article:

ZANINELLI, T. B. A View of innovation process in a collaborative perspective. AtoZ, Curitiba, v. 1, n. 2, p. 3551, jan./dec. 2012. Available from: <http://www.atoz.ufpr. br>. Access on: 